\title{
River water quality modelling under drought situations - the Turia River case
}

\author{
Javier Paredes-Arquiola, Javier Macián, María Pedro-Monzonís, Edgar Belda, Andrea Momblanch, and \\ Joaquín Andreu \\ Instituto Universitario de Ingeniería del Agua y Medio Ambiente. Universitat Politècnica de València, Valencia, \\ Spain
}

Correspondence to: Javier Paredes-Arquiola (jparedea@hma.upv.es)

Published: 17 October 2016

\begin{abstract}
Drought and water shortage effects are normally exacerbated due to collateral impacts on water quality, since low streamflow affects water quality in rivers and water uses depend on it. One of the most common problems during drought conditions is maintaining a good water quality while securing the water supply to demands. This research analyses the case of the Turia River Water Resource System located in Eastern Spain. Its main water demand comes as urban demand from Valencia City, which intake is located in the final stretch of the river, where streamflow may become very low during droughts. As a result, during drought conditions concentrations of pathogens and other contaminants increase, compromising the water supply to Valencia City. In order to define possible solutions for the above-mentioned problem, we have developed an integrated model for simulating water management and water quality in the Turia River Basin to propose solutions for water quality problems under water scarcity. For this purpose, the Decision Support System Shell AQUATOOL has been used. The results demonstrate the importance of applying environmental flows as a measure of reducing pollutant's concentration depending on the evolution of a drought event and the state of the water resources system.
\end{abstract}

\section{Introduction}

Apart from water scarcity (i.e. quantity), a relevant impact of droughts on river basins is the worsening of water quality in river systems. This can render water resources useless for economic activities and human water supply, while seriously damaging the environment (Momblanch et al., 2015). An isolated analysis of water quality limits the action measures that can be proposed. Thus, an integrated evaluation combining water management and water quality models would be desirable.

The use of a water allocation and a water quality model, integrated in the same platform, facilitates the transfer of results and allows interactive simulations, which are useful to perform scenario analysis (Momblanch et al., 2015). Water management models provide indicators about water supply reliabilities and vulnerabilities, which represent the level of satisfaction of water demands. In turn, water quality models generate time series of concentration of pollutants. The pur- pose is to select a set of target variables to capture the key aspects of the analysed water system, and to assess the effect of different alternatives on them.

Many studies have identified drought impacts, mostly on water scarcity, i.e. lack of water, with regard to human and environmental needs (Chang and Wang, 2013; Sušnik et al., 2012), which is being further associated with the drought hazard (Mishra and Singh, 2011). Besides, there are some other studies concerned about the impacts of droughts and the implicit low-flow conditions on river water quality (Barros et al., 1995; Caruso, 2002; van Vliet and Zwolsman, 2008; Paredes-Arquiola et al., 2010; Paredes et al., 2010; Whitworth et al., 2012; Momblanch et al., 2015).

In this paper we analyse the problems related to nitrates and pathogens in the Turia River System in Spain, which affect the water supply of Valencia City during droughts. Moreover, we take into account the impact of drought on irrigation water demands that represent around $80 \%$ of the total wa- 
ter use in the basin. To do so, we connect a water allocation model with a water quality model in order to test different scenarios and propose a balanced solution considering water quantity-quality tradeoffs.

\section{Material and methods}

A key objective of this research is to develop a water quality model along the Turia River to analyse the influence of nitrates, and total (TC) and faecal coliforms (FC) in the final stretch of the river, as well as building a water allocation model to assess water supply reliability for agricultural demands. For this purpose, the Decision Support System Shell (DSSS) AQUATOOL (Andreu et al., 1996) will be used. AQUATOOL comprises several modules. Firstly, the SIMGES module (Andreu et al., 1996) allows the evaluation on water resources allocation and secondly, the GESCAL module (Paredes-Arquiola et al., 2010) allows the assessment of water quality. This methodology allows us to analyse different alternatives to cope with problems triggered by droughts in the Turia River Basin. The main features of these modules are described below.

SIMGES is a general simulation model for river basins or complex water resources systems. It includes control or storage elements (surface water and groundwater) and elements for collection, transport, use and/or consumption, and artificial recharge of water. The simulation is done at a monthly scale and it can reproduce the water flow through the system at any spatial scale the user prefers. The SIMGES module also considers the return flows to the surface water system and the recharge to the groundwater system. It also takes into account the evaporation and infiltration losses from reservoirs and the interaction between surface water and groundwater. Water resources management is simulated using operation rules, which try to maintain a similar filling level in reservoirs using reservoir zone curves. It allows definition of environmental flows, as well as setting different water use priorities. The simulation and management of the surface water system are done at the same time using a network flow optimization algorithm. This algorithm determines the flows through the system trying to satisfy the multiple objectives of deficit minimization, and maximum adaptation to reservoir objective volume curves and hydroelectric production objectives. The optimization is improved through an iterative solution process of the network, what allows improving the quality of the simulated non-linear processes, such as infiltration, evaporation and surface and groundwater interaction.

GESCAL was developed to evaluate the water quality at a river basin level. For this, it includes the calculation of all processes or water quality modifications both in rivers and reservoirs. These calculations are done at every element of the river basin scheme defined with SIMGES connecting them according to the calculated flows. Applying it to different decision alternatives in the river basin management it is possible to evaluate the consequences for the water quality in different river stretches. GESCAL allows for the modelling of water temperature, arbitrary constituents, dissolved oxygen, biological oxygen demand (BOD), the nitrogen cycle, phytoplankton and phosphorous. Arbitrary constituents are defined as those for which degradation can be modelled as a first-order kinetic and/or with a sedimentation velocity. Dissolved oxygen can be considered with three possible levels of complexity. The simplest level considers BOD and dissolved oxygen. The intermediate level considers the cycle of nitrogen and the effect on dissolved oxygen, and organic nitrogen, ammonia, and nitrates. The highest level of complexity of BOD models includes the nitrogen cycle, phytoplankton, and the phosphorous cycle, as well as their relationships and the effects on dissolved oxygen. A detailed description of the processes and the model can be found in Paredes et al. (2004).

The first step represents the development of the water management and water quality models, which will be calibrated and validated. At this step, it is very important to include a drought period in the calibration and validation to ensure that the models adequately represent the performance of the system in this specific situation (Momblanch et al., 2015). The results from the calibrated models represent the baseline situation, which will be used as the reference scenario. The analysis of the calibration outcome and the initial results will provide key information to recognize the main problems occurring in the basin.

In the second step, the action measures are designed and combined to generate reasonable and realistic scenarios, in line with the water quantity and quality problems identified in the Turia River Basin during droughts. Thus, the measures that can be simulated are referred either to water quantity or water quality actions. It is important to select the proper target variables that represent the evolution of the addressed problems.

As a final step, it is necessary to analyse the existing tradeoffs by means of the target variables for the selection of the measures or sequence of measures that best facilitate the mitigation of drought effects.

\section{Case study: the Turia River Basin}

\subsection{Characterization of the study area}

The Turia River Basin (TRB) is located in the eastern part of the Iberian Peninsula in Spain (Fig. 1). It is the second most extensive basin $\left(6393 \mathrm{~km}^{2}\right)$ and water resources producer in the Jucar River Basin District. The Turia River has a length of $280 \mathrm{~km}$, traversing the provinces of Teruel, Cuenca and Valencia, and it has its mouth in the city of Valencia at the Mediterranean Sea. Hence, it is a characteristic Mediterranean river, heavily affected by drought events, presenting large differences in flow in different seasons. The main reservoirs are Arquillo de San Blas, Benagéber and Loriguilla. 


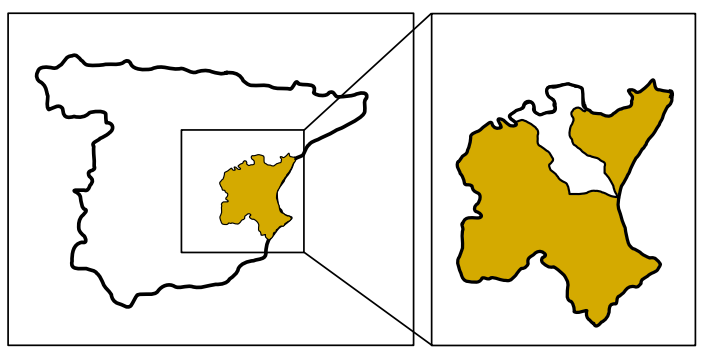

Figure 1. Location of Turia River (right) in the Jucar River Basin (Source: http://www.chj.es).

The main water demands in the basin are agrarian and urban. Along its middle and lower stretch three agrarian demands are located: the Campo del Turia, Pueblos Castillos and Tradicionales. The Campo del Turia and Pueblos Castillo irrigation demands are located in the middle part of the system and the Tradicionales in the lower basin. The main urban demand is the supply to Valencia City, which has a population of 1 million inhabitants, and its intake is located near the Tradicionales agricultural intake.

The basin has different problems related with water quantity and quality. One of the main problems is the allocation of water among agrarian demands during drought periods. Droughts are common in this basin and during these periods there is not enough water for the three above-mentioned demands. Therefore, reductions in the water supplies have to be applied. Under this consideration, flows are lower because management tries to keep water in the reservoirs and consequently an increased concentration of pollutants is measured in the river. This causes a significant problem in the lower stretch of the river due to high concentrations of nitrates and pathogens. It is not just an environmental problem; also human health is affected since the intake of water for Valencia City is located in the lower zone. The origin of nitrates pollution is the return of flows from agrarian activities in the middle river stretch. On the other hand, urban runoff and effluents from Waste Water Treatment Plants (WWTPs), also located in the middle river stretch, are responsible for the pathogen pollution. Therefore, there is an increment of pathogens and other compounds in the river, among others TC, FC, and Escherichia Coli.

\subsection{Model building}

The necessary data to develop the water resource quality model are:

- Streamflow time series measured in gauging stations and reservoirs levels. Time series of water supplies to agrarian and urban demands. A naturalization of streamflow has been done taking into account streamflow time series measured in the gauging stations, reservoirs levels and water supplies to agrarian and urban demands.

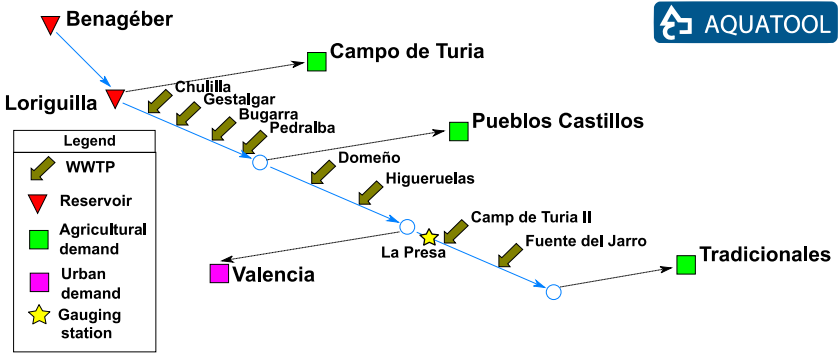

Figure 2. Scheme of the simulation model. The fundamental elements characterizing the Jucar River Basin.

- Environmental flows have also been considered, i.e. the model includes $0.7 \mathrm{~m}^{3} \mathrm{~s}^{-1}$ downstream the Benagéber Reservoir, $0.5 \mathrm{~m}^{3} \mathrm{~s}^{-1}$ downstream the Loriguilla Reservoir, and $1 \mathrm{~m}^{3} \mathrm{~s}^{-1}$ upstream the Repartiment Weir.

- Turbined flows in hydropower stations are also taken into account.

- Water volume and pollutant concentrations treated in WWTPs, which discharge in the river, time series of pollutant concentrations recorded in the quality stations located along the river and water temperature in different locations in the river.

Figure 2 shows the scheme of the SIMGES and GESCAL models used to estimate the water quality in which the different elements of the system are identified.

\subsection{Calibration of the model}

The water allocation model has been calibrated and validated. An easy way to do this is by comparing the real volumes measured in the main gauging stations of the system with the simulated volumes in the same points of the model. This was done for the period October 2004 to September 2014. The observed and simulated series were very similar, and thus the water allocation model was considered valid to conduct the proposed drought impact and management analysis (Fig. 3).

The water quality model was developed in order to simulate the concentrations of nitrates, TC and FC along the river. The calibration of the water quality model consisted of adjusting the parameters, which control the physical, chemical and biological processes causing variations in the concentrations of the considered compounds. Notice that whenever the measurements were done, they were considered as representative values of a whole month because GESCAL works on monthly stationary basis. Thus, the calibration focused on the similarity of observed and simulated tendencies instead of looking for a perfect match. The parts of the river, which required a bigger calibration effort were the lower sections due to the high concentration of urban discharges. 
Water flows in La Presa gauging station (ROEA 25)

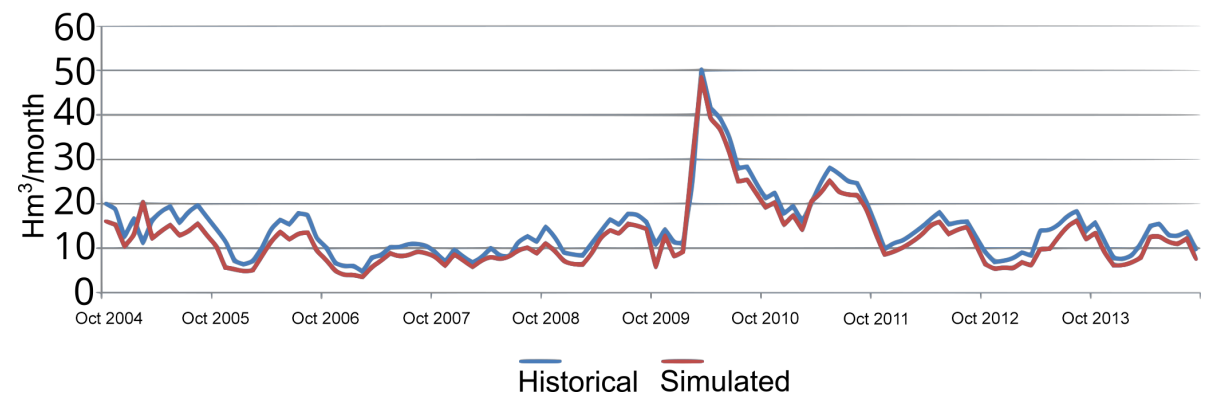

Figure 3. Comparison of water flows observed in La Presa and simulated by the model.

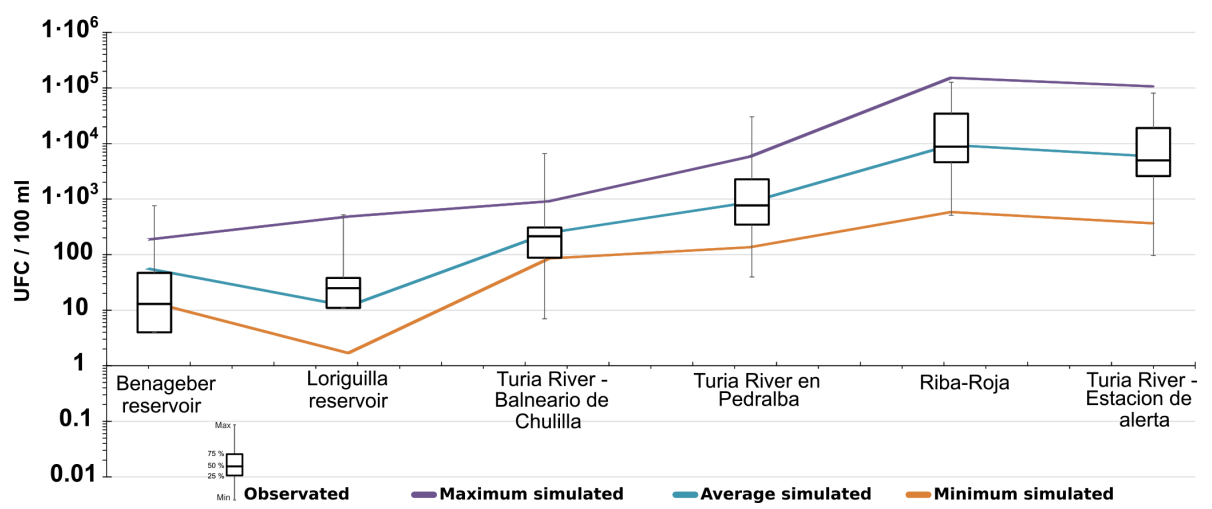

Figure 4. Adjustment between maximum, mean and minimum concentrations of TC observed and simulated along the Turia River.

Maximum, average and minimum concentrations observed and simulated along the Turia River are presented in Fig. 4. The outcome from the calibration shows a good agreement between the observed and simulated values. So, finally, the water quality model was also ready to perform the simulations required for the scenarios, i.e. exploration of measures.

\subsection{Simulation of scenarios}

Model outcome was used to explore improvement of the water quality of the river in the vicinity of the Valencia City intake, while maintaining reliability of agrarian water demands. In order to achieve this goal, several scenarios have been considered that impose different minimum flows just upstream of the Valencia City intake. The imposed minimum flows range from $8 \mathrm{~m}^{3} \mathrm{~s}^{-1}$ (current historical minimum flow) to $20 \mathrm{~m}^{3} \mathrm{~s}^{-1}$.

A traditional measure of reliability for agrarian water demand is the maximum supply deficit of the demand in one year and the maximum deficit in two consecutive years. On the other hand, resiliency is measured as the maximum number of consecutive months with deficit.

As presented in Table 1, imposed minimum flows up to $12 \mathrm{~m}^{3} \mathrm{~s}^{-1}$ can be adopted without significant increments of agrarian deficits (compare MINFLOW12 with current situation). Flows of $14 \mathrm{~m}^{3} \mathrm{~s}^{-1}$ or more imply a substantial increase of deficits, which would mean important economic consequences for farmers.

It is important to notice that imposing high river flows near the drinking water intake $\left(16,18\right.$ or $\left.20 \mathrm{~m}^{3} \mathrm{~s}^{-1}\right)$ implies that in some drought periods there is not enough water to maintain such minimum flows, since it involves releasing too much water in periods when it is not necessary. This is reflected in Table 1 by the difference between "Imposed" and "Model" figures for each scenario. The "Imposed" minimum flow is the boundary condition predefined in the model, while the "Model" minimum flow is the flow at the analysed river stretch resulting from the simulation.

Regarding water quality aspects, Fig. 5 shows that the increase of river flow decreases concentrations of TC and FC overall in the critical periods. According to Spanish legislation, drinking water treatment plants, which apply intense physical and chemical treatment, refining, and disinfection (A3 type), should not use raw water with TC concentration above $50000 \mathrm{UFC} / 100 \mathrm{~mL}$. This is the case of the plant supplying Valencia City. Results show that the increase of minimum flows reduces TC concentrations to or below the legal threshold all along the simulated period, except for October 2007. Even imposing an envi- 
Table 1. Summarised results for the reliability (Max Def 1 year (\%): maximum annual water supply deficit as \% of the annual water demand; Max Def 2 consecutive years (\%): maximum accumulated water supply deficit in two consecutive years as \% of the annual water demand) and resiliency (maximum number of consecutive months with deficit) of the three agricultural water demands for the current situation and for different imposed minimum flows at river stretch where the Valencia City water intake (VWI) is located (MINFLOW: 12, 14, 16, 18 and $\left.20 \mathrm{~m}^{3} \mathrm{~s}^{-1}\right)$.

\begin{tabular}{|c|c|c|c|c|c|c|c|c|c|}
\hline & \multicolumn{3}{|c|}{ Current SITUATION } & \multicolumn{3}{|c|}{ MIN FLOW 12} & \multicolumn{3}{|c|}{ MIN FLOW 14} \\
\hline & \multicolumn{3}{|c|}{ Minimum Flow in VMI } & \multicolumn{3}{|c|}{ Minimum Flow in VMI } & \multicolumn{3}{|c|}{ Minimum Flow in VMI } \\
\hline & Imposed & $\begin{array}{l}\text { Model } \\
8\end{array}$ & & $\begin{array}{l}\text { Imposed } \\
12\end{array}$ & $\begin{array}{l}\text { Model } \\
12\end{array}$ & & $\begin{array}{l}\text { Imposed } \\
14\end{array}$ & $\begin{array}{l}\text { Model } \\
14\end{array}$ & \\
\hline & $\begin{array}{l}\text { Max Def } 1 \\
\text { year }(\%)\end{array}$ & $\begin{array}{l}\text { Max Def } 2 \\
\text { consecutive } \\
\text { years }(\%)\end{array}$ & Resiliency & $\begin{array}{l}\text { Max Def } 1 \\
\text { year }(\%)\end{array}$ & $\begin{array}{l}\text { Max Def } 2 \\
\text { consecutive } \\
\text { years (\%) }\end{array}$ & Resiliency & $\begin{array}{l}\text { Max Def } 1 \\
\text { year }(\%)\end{array}$ & $\begin{array}{l}\text { Max Def } 2 \\
\text { consecutive } \\
\text { years (\%) }\end{array}$ & Resiliency \\
\hline Campo del Turia & 25.5 & 50.2 & 24.0 & 25.5 & 50.2 & 24.0 & 25.5 & 50.2 & 24.0 \\
\hline Pueblos Castillos & 29.5 & 48.3 & 24.0 & 30.0 & 48.7 & 24.0 & 35.5 & 54.3 & 24.0 \\
\hline \multirow[t]{5}{*}{ Tradicionales } & 16.1 & 30.6 & 24.0 & 16.2 & 30.7 & 24.0 & 17.3 & 31.8 & 24.0 \\
\hline & \multicolumn{3}{|c|}{ MIN FLOW 16} & \multicolumn{3}{|c|}{ MIN FLOW 18} & \multicolumn{3}{|c|}{ MIN FLOW 20} \\
\hline & \multicolumn{3}{|c|}{ Minimum Flow in VMI } & \multicolumn{3}{|c|}{ Minimum Flow in VMI } & \multicolumn{3}{|c|}{ Minimum Flow in VMI } \\
\hline & $\begin{array}{l}\text { Imposed } \\
16\end{array}$ & $\begin{array}{l}\text { Model } \\
8.2\end{array}$ & & $\begin{array}{l}\text { Imposed } \\
18\end{array}$ & $\begin{array}{l}\text { Model } \\
8.2\end{array}$ & & $\begin{array}{l}\text { Imposed } \\
20\end{array}$ & $\begin{array}{l}\text { Model } \\
8.2\end{array}$ & \\
\hline & $\begin{array}{l}\text { Max Def } 1 \\
\text { year }(\%)\end{array}$ & $\begin{array}{l}\text { Max Def } 2 \\
\text { consecutive } \\
\text { years (\%) }\end{array}$ & Resiliency & $\begin{array}{l}\text { Max Def } 1 \\
\text { year }(\%)\end{array}$ & $\begin{array}{l}\text { Max Def } 2 \\
\text { consecutive } \\
\text { years }(\%)\end{array}$ & Resiliency & $\begin{array}{l}\text { Max Def } 1 \\
\text { year }(\%)\end{array}$ & $\begin{array}{l}\text { Max Def } 2 \\
\text { consecutive } \\
\text { years }(\%)\end{array}$ & Resiliency \\
\hline Campo del Turia & 25.8 & 51.4 & 28.0 & 25.8 & 51.4 & 28.0 & 29.0 & 56.1 & 34.0 \\
\hline Pueblos Castillos & 56.5 & 87.0 & 28.0 & 74.3 & 125.6 & 28.0 & 78.0 & 148.1 & 34.0 \\
\hline Tradicionales & 17.8 & 33.0 & 28.0 & 16.4 & 31.6 & 28.0 & 19.0 & 36.0 & 34.0 \\
\hline
\end{tabular}

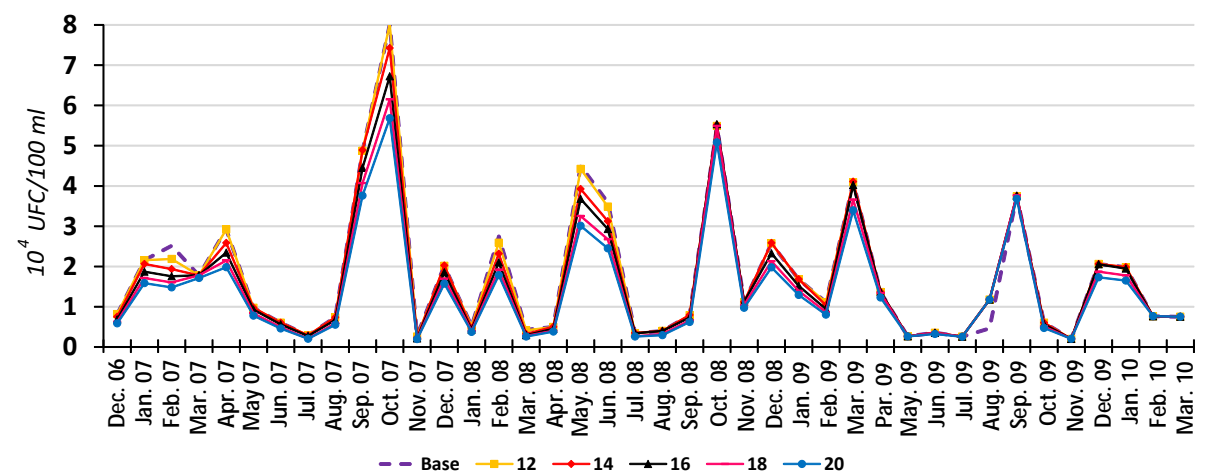

Figure 5. Concentrations of simulated Total Coliforms (TC) near the intake of Valencia City water for different environmental flow (imposed minimum flow) conditions.

ronmental flow of $20 \mathrm{hm}^{3}$ month ${ }^{-1}$, concentrations remain above $50000 \mathrm{UFC} / 100 \mathrm{~mL}$. However, the global situation improves. Moreover, according to the results, it is not necessary to maintain the minimum flow all the time since most of the simulated period TC concentrations stay between 20000 and $30000 \mathrm{UFC} / 100 \mathrm{~mL}$, which are more than acceptable concentrations. Hence it would be better to define a variable minimum flow regime, which allows keeping water in the reservoirs when it is not necessary for water quality issues, and which ensures increased river flows when pollution peaks occur.
Other alternatives have also been taken into consideration, such as disinfection treatments in different WWTPs, but even in the optimal scenarios, an increase of water releases from the reservoirs is necessary to reduce pathogens in the Valencia City water intake.

\section{Conclusions}

In this study a water quantity-quality model for the Turia River has been developed. This model allowed us to analyse the influence of total (TC) and faecal coliforms (FC) in the raw water arriving to the Valencia City water supply in- 
take. The integral model allows exploring integral solutions taking into account water quantity and quality aspects. The obtained results have demonstrated the efficacy of applying environmental flows as a measure to reduce concentration of water pollutants during drought conditions. According to the results, it is not necessary to maintain a minimum flow continuously, but during drought conditions, an increase in river flow may help to improve the water quality.

\section{Data availability}

All raw data is available on the Jucar River Basin Webpage (http://www.chj.es/). More specific information can be found in appendix 6 of river basin management plan 2015-2021 (http://www.chj.es/Descargas/ProyectosOPH/ Consultapublica/PHC-2015-2021/PHJ1521_Anejo06_ SE-Balances_151126.pdf).

Acknowledgements. The authors wish to thank the European Community's Seventh Framework Program in financing the project ENHANCE (FP7-ENV-2012, 308438), as well as the support of the "Pioneers into Practice Programme" of Climate-KIC for creating opportunities, and the framework for innovators to address climate change and shape the world's next economy. The authors acknowledge the support of the Polytechnic University of Valencia (grant agreement number 4234) through its Support Programme for Research.

\section{References}

Andreu, J., Capilla, J., and Sanchís, E.: AQUATOOL, a generalized decision-support system for water-resources planning and operational management, J. Hydrol., 177, 269-291, doi:10.1016/00221694(95)02963-X, 1996.

Barros, M. C., Mendo, M. J. M., Negrão, F. C. R.: Surface water quality in Portugal during a drought period, Sci. Total Environ., 171, 69-76, doi:10.1016/0048-9697(95)04671-7, 1995.

Caruso, B. S.: Temporal and spatial patterns of extreme low flows and effects on stream ecosystems in Otago, New Zealand, J. Hydrol., 257, 115-133, doi:10.1016/S0022-1694(01)00546-7, 2002.
Chang, F.-J. and Wang, K.-W.: A systematical water allocation scheme for drought mitigation, J. Hydrol., 507, 124-133, doi:10.1016/j.jhydrol.2013.10.027, 2013.

Confederación Hidrogràfica del Júcar: River basin management plan 2015-2021, available at: http://www.chj.es/Descargas/ ProyectosOPH/Consultapublica/PHC-2015-2021/PHJ1521_ Anejo06_SE-Balances_151126.pdf, 2015 (in Spanish).

Mishra, A. K. and Singh, V. P.: Drought modeling - A review, J. Hydrol., 403, 157-175, doi:10.1016/j.jhydrol.2011.03.049, 2011.

Momblanch, A., Paredes-Arquiola, J., Munné, A., Manzano, A., Arnau, J., and Andreu, J.: Managing water quality under drought conditions in the Llobregat River Basin, Sci. Total Environ., 503504, 300-318, doi:10.1016/j.scitotenv.2014.06.069, 2015.

Paredes, J.: Integración de la modelación de la calidad del agua en un sistema de ayuda a la decisión para la gestión de recursos hídricos, Universitat Politècnica de València, Valencia (Spain), doi:10.4995/Thesis/10251/1895, 2004.

Paredes, J., Andreu, J., and Solera, A.: A decision support system for water quality issues in the Manzanares River (Madrid, Spain), Sci. Total Environ., 408, 2576-2589, doi:10.1016/j.scitotenv.2010.02.037, 2010.

Paredes-Arquiola, J., Andreu-Álvarez, J., Martín-Monerris, M., and Solera, A.: Water quantity and quality models applied to the Jucar River Basin, Spain, Water Resour. Manag., 24, 2759-2779, 2010.

Sušnik, J., Vamvakeridou-Lyroudia, L. S., Savić, D. A., and Kapelan, Z.: Integrated System Dynamics Modelling for water scarcity assessment: Case study of the Kairouan region, Sci. Total Environ., 440, 290-306, doi:10.1016/j.scitotenv.2012.05.085, 2012.

Van Vliet, M. T. H. and Zwolsman, J. J. G.: Impact of summer droughts on the water quality of the Meuse River, J. Hydrol., 353, 1-17, doi:10.1016/j.jhydrol.2008.01.001, 2008.

Whitworth, K. L., Baldwin, D. S., and Kerr, J. L.: Drought, floods and water quality: Drivers of a severe hypoxic blackwater event in a major river system (the southern MurrayDarling Basin, Australia), J. Hydrol., 450-451, 190-198, doi:10.1016/j.jhydrol.2012.04.057, 2012. 